\title{
ANALISIS PERBANDINGAN KINERJA REKSA DANA SAHAM SYARIAH DAN KONVENSIONAL PERIODE 2012-2015
}

\author{
Nurul Huda \\ Program Studi Magister \\ nurul.huda@yarsi.ac.id
}

Nazwirman

Manajemen Universitas YARSI

nazwirman@yarsi.ac.id

Khamim Hudori

Alumni PSKTTI Universitas Indonesia

\section{Abstrak}

Penelitian ini bertujuan untuk menganalisis kinerja reksadana saham syariah dan konvensional. Metode yang digunakan yaitu indeks Sharpe, Treynor, Jensen, appraisal ratio, $\mathrm{M}^{2}$ measure, dan $\mathrm{T}^{2}$ measure selama periode Januari 2012 sampai 
dengan Desember 2015. Sample untuk Rekasadana konvensional sebanyak 25 emiten dan reksadana syariah sebanyak 7 sampel. Hasil penelitian kinerja reksadan saham syariah secara rata-rata lebih baik dibandingkan dengan konvensional, hanya saja berdasarkan pengujian dua sampel perbandingan tidak terdapat perbedaan yang berarti antara kinerja reksadana saham konvensional dan syariah.

Kata Kunci : Reksadana, saham, Konvensional, syariah, kinerja

\section{Abstract}

This study aimed to analyse the performance of Islamic and conventional mutual fund stocks. The method was used the Sharpe, Treynor, Jensen, appraisal ratio, $M^{2}$ measure and $T^{2}$ measure index during the period January 2012 to December 2015. The Number of Samples for conventional mutual fund stocks was 25 issuers and Islamic mutual funds stock as much as 7 samples. The results of the research that performance of Islamic mutual funds stock averagely was better than the conventional, The result of test comparison two samples There were no differences performance significant mutual funds stocks of conventional and Islamic.

Keywords : Mutual Fund, stocks, Conventional, Islamic, Performance 


\section{PENDAHULUAN}

Prinsip investasi Islam pada dasarnya menggunakan profit sharing, melarang riba, maisir, dan gharar (El Gamal, 2000; Elfakhani dan Hassan, 2005; Hartono, Soekarno dan Damayanti, 2014). Huda dan Mutafa (2014) menjelaskan investasi sebagai salah satu ajaran konsep Islam yang memenuhi proses Tadrij dan Trichotomy

Meskipun ketidaksepakatan terus terjadi antara pendukung dan pengamat luar mengenai perbedaan antara apa yang diizinkan atau diharuskan (halal) dan apa yang dilarang (haram) di bawah interpretasi yang berbeda dari Hukum Islam (Evans, 2015). Konsep investasi selain sebagai pengetahuan juga bernuansa spiritual karena menggunakan norma syariah, sekaligus merupakan hakikat dari sebuah ilmu dan amal, oleh karenanya investasi sangat dianjurkan bagi setiap muslim.

Reksa dana syariah bertujuan untuk memandu investor yang ingin menginvestasikan dananya secara syariah. Reksa dana syariah sebagaimana diatur dalam Peraturan Bapepam dan LK Nomor IX.A.13 didefinisikan sebagai reksa dana yang pengelolaannya tidak bertentangan dengan prinsip-prinsipsyariah dipasar modal. Sehingga reksa dana syariah hanya berinvestasi pada perusahaan dengan kategori halal. Pesatnya pertumbuhan reksa dana baik konvensional maupun syariah menghadapkan investor kepada masalah bagaimana memilih alternatif reksa dana yang ada berdasarkan kinerja reksa dana.

Reksadana

syariah berjumlah 86 sedangkan reksa dana konvensional berjumlah 951, hal ini berarti reksadana syariah hanya sebesar 8,29 persen dibandingkan total reksadana yang ada hingga November 2015. Nilai aktiva bersih (NAB) atau Net Asset Value (NAV) reksada syariah bernilai Rp 10.770,74 Milyar atau hanya sebesar $4,11 \%$ dari total NAB reksadana hingga November 2015.

$$
\text { Lailiyah, Suhadak, }
$$

Sulasmiyati

penelitiannya menganalisis terhadap 20 reksadana dengan menggunakan perhitungan metode sharpe, treynor, jensen dan pertumbuhan AUM diperoleh kesimpulan yaitu reksadana konvensional memiliki kinerja yang lebih baik dibandingkan dengan reksadana syariah jika menggunakan metode sharpe, treynor, dan pertumbuhan AUM. Hasil perhitungan 
rata-rata nilai sharpe, treynor dan pertumbuhan AUM menghasilkan nilai sharpe, nilai treynor dan pertumbuhan AUM reksadana konvensional lebih besar dibandingkan dengan reksadana syariah. Sebaliknya, jika menggunakan metode jensen reksadana syariah memiliki kinerja yang lebih baik karena memiliki rata-rata nilai jensen yang lebih tinggi daripada reksadana konvensional.

Rahmah

(2016), menuimpulkan kemampuan kinerjareksadanakonvensional lebih tinggi dibandingkan kinerja reksadana syariah. pada reksadana campuran, reksadana yang memiliki kinerja terbaik adalah reksadana konvensional. Untuk risiko, reksadana konvensional memiliki risiko sistematis yang lebih kecil.

Berdasarkan pada riset di atas maka ada kesimpulan yang masih ambigu untuk menyatakan kinerja reksadana syariah apakah lebih baik atau sebaliknya dibandingkan reksadana konvensional, sehingga diperlukan pengujian lebih lanjut dengan menambahkan beberapa metode yang tidak digunakan pada penelitian sebelumnya seperti appraisal ratio, $\mathrm{m}^{2}$ measure, dan $t^{2}$ measure pada reksadana saham.

\section{KAJIAN LITERATUR}

Reksa dana atau di Inggris lebih dikenal dengan "unit investment trusts" menurut Bodie, Kane, dan Marcus (2003) mendefinisikannya sebagai berikut.

"Unit investment trusts are pools of money invested in a portfolio that is fixed for the life of the fund. To form a unit investment trust, a sponsor, typically a brokerage firm, buys a portfolio of securities which are deposited into a trust. It then sells to the public shares, or "units," in the trust, called redeemable trust certificates".

Fatwa Dewan Syariah Nasional (DSN) No. 20/DSNMUI/IV/2001, Reksadana Syariah (Islamic Investment Funds) merupakan reksadana yang beroperasi menurut ketentuan dan prinsip-prinsip syariah Islam, baik dalam bentuk akad antara pemodal dengan manajer investasi (wakil pemodal), maupun antara manajer investasi dengan pengguna investasi.

Perbedaan mendasar Reksadana konvensional dan Syariah yaitu hanya terletak pada cara pengelolaan dan prinsip kebijakan investasi yang diterapkan. Kebijakan investasi reksa dana syariah 
adalah berbasis instrumen investasi dengan cara-cara pengelolaan yang halal. Halal berarti bahwa perusahaan yang mengeluarkan instrumen investasi tersebut tidak boleh melakukan usaha-usaha yang bertentangan dengan prinsip Islam. Misalnya,tidak melakukan perbuatan riba (membungakan uang) dan tidak memakai strategi investasi berdasarkan spekulasi, saham, obligasi dan sekuritas lainnya tidak berhubungan dengan produk minuman keras, produk yang mengandung babi, bisnis hiburan berbau maksiat, perjudian, pornografi, dan sebagainya (Huda dan Mustafa, 2014).

Reksadana

dikelompokkan

dapat beberapa jenis berdasarkan portofolio investasinya (Huda dan Mustafa, 2014; Iman, 2008 ) yaitu:

1. Reksa Dana Pasar Uang, Reksa dana jenis ini merupakan reksa dana yang hanya melakukan investasi pada efek bersifat utang dengan jatuh tempo kurang dari 1 (satu) tahun.

2. Reksa Dana Pendapatan Tetap, merupakan reksa dana yang m e n g i n v e s t a s i k a n dananya minimal $80 \%$ dari aktivanya dalam bentuk efek bersifat utang. Reksa dana ini memiliki risiko yang relatif lebih besar dari reksa dana pasar uang.

3. Reksa Dana Saham, merupakan reksa dana yang menginvestasikan dananya minimal $80 \%$ dari aktivanya dalam bentuk efek bersifat ekuitas. Karena investasinya dilakukan pada saham, maka risikonya lebih tinggi dari dua jenis reksa dana sebelumnya, namun menghasilkan tingkat pengembalian yang tinggi.

4. Reksa Dana Campuran, dapat melakukan investasinya ke surat-surat berharga ekuitas (saham), utang (pendapatan tetap), maupun instrumen pasar uang yang perbandingan alokasi dan komposisinya lebih fleksibel. Manajer investasi yang mengelola reksa dana campuran dapat mengalihkan portofolionya ke dalam surat berharga lain apabila dianggap perlu untuk mempertahankan nilai investasi pemodal atau menghadapi situasi dan kondisi yang kurang menguntungkan.

Pengukura n kinerja reksadana didasarkan pada perkembangan besaran nilai aktiva bersih (Net Asset Value/NAV). Konsep Net Asset Value (NAV) adalah nilai aktiva reksa dana setelah dikurangi 
nilai kewajiban reksa dana tersebut (Farkoosh dan Naseri, 2012; Priyadarshinil dan Babu, 2012).

Rafay, Gilani and Izhar (2017) hasil penelitiannya untuk kasus Malaysia menyimpulkan kinerja return dan volatilitas reksadana syariah dan konvensional konsisten.

Putra dan Mawardi (2016) menyimpulkan bahwa tidak ada perbedaan kinerja antara reksadana syariah saham, reksadana syariah campuran, dan reksadana syariah pendapatan tetap dengan menggunakan metode sharpe pada tahun 2012, 2013, 2014. Berdasarkan hasil perhitungan rata - rata kinerja reksadana syariah per bulan dari tahun 2012 hingga 2014, reksadana syariah saham adalah reksadana yang memiliki kinerja terbaik dibanding kedua jenis reksadana lainnya. Nilai pehitungan rata - rata kinerja reksadana syariah menggunakan metode sharpe periode 2012 hingga 2014 untuk reksadana syariah saham adalah 0,72. Nilai kinerja tersebut lebih tinggi dibandingkan dari nilai kedua jenis kenerja reksadana syariah lainnya.

Sunarsih dan Adrianto, (2015) meneliti Analysis of the Performance of Islamic Mutual
Funds in Indonesia by using Sharpe, Treynor and Jensen the Period 2010-2012 menggunakan data yang dipublikasikan Bapepam LK (25 emiten) hasil yang diperoleh selama tahun 2010 kinerja reksadana positif. Tahun 2011 terdapat 11 reksadana mempunyai kinerja positif dan 14 mempunyai kinerja negatif dan tahun 2012 terdapat 19 reksadana memupunyai kinerja positif dan 6 mempunyai kinerja negatif

Penelitian Putra dan Fauzie (2014) dengan judul “ Analisis Perbandingan Kinerja Reksa Dana Konvensional Dengan Reksa Dana Syariah Di Indonesia dengan sampel seluruh jenis Reksadana yang dikelola 21 perusahaan manajemen investasi periode 2011-2013 dengan menggunakan metode Sharpe, Treynor, Jensen. Hasil yang diperoleh secara rata-rata kinerja reksa dana syariah lebih baik dibandingkan kinerja Reksa dana konvensional. Ashraf dan Fahd (2013), hasil penelitiannya menyimpulkan kinerja Islamic Mutula Fund (IMF) di Arab Saudi lebih baik dibandingkan dengan konvensional selama periode krisis ekonomi. Selain itu, walaupun tidak ada bukti keunggulan relatif dalam kemampuan waktu pasar, manajer IMF tampaknya 
memiliki kemampuan seleksi saham yang lebih baik selama masa krisis ekonomi.

Ratnawati dan Khairani (2012) melakukan penelitian dengan menggunakan Sharpe Ratio, Treynor Ratio, dan Jensen Ratio untuk melihat bagaimana perbedaan kinerja antara reksa dana syariah dan reksa dana konvensional. Hasilnya adalah kinerja reksa dana syariah dan konvensional memang berbeda tetapi tidak signifikan.

Dewi dan Ferdian (2012) melakukan penelitian dengan judul Evaluating Performance of Islamic Mutual Funds in Indonesia and Malaysia dengan menggunakan 10 sampel reksadana Indonesia dan 14 Reksadana Malaysia. Metode yang digunakan Sharpe Ratio, Treynor Ratio, Jensen Ratio, Snail Trail Method dan market Timing. Hasil riset memperlihatkan reksadana syarian Indonesia sedikit mengunguli Malaysia dalam hal alokasi dana.

Desiana dan Isnurhadi (2012) melakukan penelitian mengenai perbandingan kinerja reksa dana saham konvensional dengan reksa dana saham syariah di Bursa Efek Indonesia. Data dalam penelitian ini menggunakan saham reksa dana konvensional dan saham reksa dana syariah yang terdaftar di Bursa Efek Indonesia. Metode penelitian yang digunakan adalah Independent T-Test untuk data distribusi normal, dan Mann Whitney Test untuk data distribusi tidak normal. Hasil dari penelitian ini menunjukkan kinerja reksa dana konvensional saham memiliki kinerja baik (outperform) dibandingkan dengan kinerja reksa dana saham syariah sesuai dengan pengukuran kinerja reksa dana Sharpe, Treynor, dan Jensen. Rata-rata return dan risiko reksa dana saham syariah untuk periode Januari 2005 sampai dengan Desember 2011 di bawah return dan risiko pasar. Rata-rata return dan risiko reksa dana saham konvensional untuk periode Januari 2005 sampai dengan Desember 2011 di atas return dan risiko pasar.

\section{METODE PENELITIAN}

Penelitian menggunakan pendekatan kuantitatif melalui pendekatan indeks dan uji statistik dengan hipotesis perbedaan rata-rata untuk masing-masing perbandingan. Sampel reksadana saham konvensional sebanyak 25 emiten dan syariah sebanyak 7 emiten.

Pengumpulan data,
seleksi data, menghitung
return NAB reksa dana, return
market, dan return risk free. 
Selanjutnya, menghitung kovarians, standar deviasi, beta portofolio, menghitung risk adjusted return dengan indeks sharpe, treynor dan jensen, lalu membuat pemeringkatan reksa dana melalui pendekatan indeks sharpe, treynor, jensen, appraisal ratio, $M^{2}$ measure, dan $T^{2}$ measure. Proses berikutnya melakukan uji Paired-Samples $T$ Test rata-rata kinerja reksa dana saham konvensional dan syariah untuk periode Januari 2012 sampai dengan Desember 2015. Proses terakhir, uji statistik dengan hipotesis perbedaan rata-rata untuk masing-masing perbandingan.

Return yang dimaksud dalam penelitian ini adalah harga Nilai Aktiva Bersih per Unit Penyertaan (NAB/UP) dari periode tertentu atau $t_{0}$ dikurangi harga NAB/UP pada periode sebelumnya. Formulasi perhitungan return (Bodie, 2011) sebagai berikut.

$\mathrm{Rp}=\frac{\mathrm{NABperunit}_{1}-\mathrm{NABperunit}_{0}}{\text { NABperunit }_{0}}$

Di mana:

$\operatorname{Rp} \quad=$ Return Reksa

Dana

NABperunit $_{1}=\mathrm{NAB} / \mathrm{UP}$ pada akhir periode

NABperunit $_{0}=\mathrm{NAB} / \mathrm{UP}$ pada awal periode
Selanjutnya dihitung
average return
pengembalingkat
dengan cara membagi total return dengan jumlah bulan (n) pada periode tertentu.

$\mathrm{Ra}=\frac{\sum \mathrm{Rp}}{\mathrm{n}}$

Di mana:

$\mathrm{Ra}=$ Average return

$\sum \mathrm{Rp}=$ Jumlah return reksa dana pada periode tertentu

n = Jumlah bulan

Selain return reksa

dana, return IHSG, JII, dan SBI juga dihitung dengan menggunakan rumus yang sama seperti menghitung return NAB reksa dana.

Varians dan standar deviasi merupakan cara untuk mengukur volatility return suatu sekuritas (Ross, 2003). Rumus varians dapat dilihat sebagai berikut.

$\sigma^{2}=\frac{\sum\left(X_{i}-\bar{X}\right)^{2}}{n-1}$

Di mana:

$\mathrm{\sigma}^{2} \quad=$ Variance

$\mathrm{X}_{\mathrm{i}} \quad=$ Actual Return

$\mathrm{X}=$ Average Return

$\mathrm{n}-1=$ Jumlah observasi dikurangi satu

Rumus standar deviasi adalah akar kuadrat dari varians, dirumuskan sebagai berikut. 


$$
\sigma=\sqrt{\frac{\sum\left(X_{i}-\bar{X}\right)^{2}}{\operatorname{RoSS}^{n-1},(2003) \text { menjelaskan }}}
$$

standar deviasi adalah standar yang digunakan untuk mengukur total level risiko suatu portofolio.

Beta adalah ukuran relatif dari risiko saham individu terhadap portofolio saham keseluruhan. Jika return sekuritas bergerak lebih cepat dari return pasar karena adanya perubahan pasar, maka return sekuritas tersebut dikatakan mempunyai volatilitas (fluktuasi return saham) yang lebih besar daripada return pasar. Perhitungan nilai beta dari produk reksa dana dalam perhitungan ini digunakan persamaan sebagai berikut (Ross, 2003)

$$
\beta_{\mathrm{p}}=\frac{\operatorname{Cov}_{\mathrm{m}}}{\sigma_{\mathrm{m}}^{2}}
$$

di mana:

$\beta_{\mathrm{p}}=$ Beta dari portofolio

$\operatorname{Cov}_{\mathrm{im}} \stackrel{\mathrm{p}}{=}$ Return covariance antara portofolio $\mathrm{p}$ $\sigma_{m}^{2} \quad$ dan pasar m pasar $\mathrm{m}$

Varians portofolio terdiri dari komponen systematic dan komponen nonsystematic, seperti terlihat pada persamaan di bawah ini (Bodie, 2009)

$$
\sigma_{\mathrm{p}}^{2}=\beta_{\mathrm{p}}^{2} \sigma_{\mathrm{m}}^{2}+\sigma^{2}\left(\varepsilon_{\mathrm{p}}\right)
$$

Di mana:

$\sigma_{\mathrm{p}}^{2}=$ Varians dari reksa dana

$\beta_{\mathrm{p}}^{2} \sigma_{\mathrm{m}}^{2}=$ Komponen systematic dari varians reksa dana $\sigma^{2}\left(\varepsilon_{p}\right)=K$ o m p o n e $n$ nonsystematic dari varians reksa dana.

Bodie

(2009)

menjelaskan tracking error dari sebuah produk reksa dana adalah akar dari komponen nonsystematic dari varians portofolio. Berdasarkan persamaan (6), untuk mendapatkan tracking error maka persamaannya menjadi sebagai berikut.

$$
\sigma\left(\varepsilon_{\mathrm{p}}\right)=\sqrt{\sigma_{\mathrm{p}}^{2}-\beta_{\mathrm{p}}^{2} \sigma_{\mathrm{m}}^{2}}
$$

Di mana:

$\sigma\left(\varepsilon_{\mathrm{p}}\right)=$ tracking error

$\sigma_{\mathrm{p}}^{2}=$ Varians dari reksa dana

$\beta_{\mathrm{p}}^{2}=$ Kuadrat dari nilai Beta reksa dana

$\sigma_{\mathrm{m}}^{2} \quad=$ Varians dari pasar

Pengukuran dengan metode sharpe pada "Risk Premium". Risk premium adalah perbedaan (selisih) antara rata-rata kinerja yang dihasilkan oleh reksa dana dan rata-rata kinerja investasi yang bebas risiko (risk free 
asset). Investasi tanpa risiko diasumsikan merupakan tingkat bunga rata-rata dari Sertifikat Bank Indonesia (SBI). Risk free asset dalam penelitian ini diasumsikan sebagai SBI. Pengukuran Sharpe diformulasikan sebagai ratio risk premium terhadap standar deviasinya. Metode sharpe dirumuskan sebagai berikut (Bodie, 2003)

Sharpe's Measure $=\frac{\left(\overline{r_{p}}-\overline{r_{f}}\right)}{\sigma_{\mathrm{p}}} .$.

Di mana:

$\overline{r_{p}} \quad=$ Rata-rata return reksa dana pada periode tertentu

$\overline{r_{f}}=$ Rata-rata kinerja investasi bebas risiko pada periode tertentu

$\sigma_{\mathrm{p}} \quad=$ Standard deviasi reksa dana pada periode tertentu

Pratomo dan Nugraha Ratnawati dan Khairani, (2012) menjelaskan Sharpe mengukur risk premium melalui metode membagi risk premium dengan standar deviasi yang dihasilkan per unit risiko yang diambil. Semakin tinggi nilai rasio Sharpe semakin baik pula kinerja reksa dana tersebut. Bodie

menjelaskan kinerja (2009) menggunakan metode treynor yaitu pengukuran kinerja didasarkan excess return reksa dana pada periode tertentu dengan beta reksa dana pada periode tertentu. Excess return merupakan selisih antara tingkat pengembalian ratarata inventasi portofolio dengan tingkat pengembalian rata-rata inventasi yang bebas risiko. Pada metode treynor menggunakan pembagi beta $(\beta)$ yang merupakan systemastic risk. Systemastic risk merupakan risiko fluktuasi terhadap risiko pasar. Pengukuran kinerja dengan metode Treynor dirumuskan sebagai berikut.

Treynor's Measure $=\frac{\left(\overline{r_{p}}-\overline{r_{f}}\right)}{\beta_{\mathrm{p}}}$

Di mana:

$\overline{r_{p}} \quad=$ Rata-rata return reksa dana pada periode tertentu

$\overline{r_{f}} \quad=$ Rata-rata kinerja investasi bebas risiko pada periode tertentu

$\beta_{p} \beta_{p}=$ Beta portofolio

Semakin tinggi nilai rasio treynor, semakin baik kinerja reksa dana (Bodie, 2009).

$\mathrm{P}$ e $\mathrm{n} \mathrm{g} \mathrm{u}$ k $\mathrm{r}$ a $\mathrm{n}$ kinerja reksa dana dengan menggunakan metode Jensen didasarkan atas Capital Asset Pricing Model (CAPM). Persamaan dari pengukuran 
kinerja metode Treynor adalah mengukur selisih dari ratarata return reksa dana dengan nilai expected return reksa dana yang didapatkan dari hasil perhitungan (Al-Khalazi et al., 2014; Dewi dan Ferdian, 2012; Habib dan Islam, 2014; Jawadi et al., 2014)

Pengukuran kinerja dengan metode Jensen dirumuskan (Bodie, 2009) sebagai berikut.

$\mathrm{\alpha}=\bar{r}_{p}-\left[\bar{r}_{f}+\beta_{p}\left(\bar{r}_{m}-\bar{r}_{f}\right)\right] \ldots(10)$

Di mana:

a = Jensen's alpha

$\overline{r_{p}} \quad=$ Rata-rata return portofolio

$\overline{r_{f}} \quad$ = Rata-rata return aset bebas risiko

$\bar{r}_{m} \quad=$ Rata-rata return pasar

$\beta_{\mathrm{p}}=$ Beta (systematic risk) portofolio

Semakin tinggi hasil dari $a_{p^{\prime}}$ maka semakin baik juga kinerja reksa dana yang diukur (Sutawisena, 2011). Sutawisena

(2011) menyatakan appraisal ratio merupakan pengukuran kinerja reksa dana terhadap risk adjusted return pada financial security, baik berupa aset maupun portofolio. Pengukuran kinerja dengan metode Appraisal Ratio dirumuskan sebagai berikut (Bodie et al., 200" '. $\alpha$ Appraisal ratio $=\frac{a}{\sigma\left(\varepsilon_{p}\right)}$
Di mana:

$\mathrm{a}_{\mathrm{p}} \quad=$ alpha reksa dana $\mathrm{p}$

$\sigma\left(\varepsilon_{\mathrm{p}}\right)=$ nonsystematic risk (tracking error)

Appraisal

mengukur kemampuan superior manajer investasi untuk setiap risiko nonsystematic yang dimiliki. Semakin tinggi nilai appraisal Ratio, maka semakin baik kinerja reksa dana yang diukur (Sutawisena, 2011).

Pengukuran kinerja reksa dana dengan $M^{2}$ Measure adalah pengukuran yang menghitung selisih antara return pasar dengan return reksa dana jika total risikonya disamakan. Maka persamaannya adalah sebagai berikut (Bodie et al., 2011).

$\omega_{p}=\frac{\sigma_{m}}{\sigma_{p}}$

\section{Di mana:}

$\omega_{\mathrm{p}}=$ Bobot investasi $\mathrm{di}$ reksa dana

$\sigma_{m} \quad=$ Standar deviasi pasar

$\sigma_{p} \quad=$ Standar deviasi reksa dana

Persamaan untuk

menghitung $\omega_{\mathrm{Rf}} \quad$ (bobot investasi di instrumen bebas risiko) adalah sebagai berikut (Bodie et al., 2011).

$\omega_{\mathrm{Rf}}=1-\omega_{\mathrm{p}}$

Setelah mendapatkan bobot investasi, selanjutnya adalah menghitung return $\mathrm{R}_{\mathrm{p}^{*}}$. 
Persamaan yang digunakan adalah sebagai berikut.

$R_{p^{*}}=\left(\omega_{\mathrm{p}} \times R_{p}\right)+\left(\omega_{\mathrm{Rf}} \times R_{f}\right) \ldots$

Di mana:

$\omega_{\mathrm{p}}=$ bobot investasi $\mathrm{di}$ reksa dana

$R_{p} \quad=$ return reksa dana

$\omega_{\mathrm{Rf}}=$ bobot investasi di instrumen bebas risiko

$R_{f}=$ return instrumen bebas risiko

B e $\mathrm{r}$ i $\mathrm{k} \mathrm{u} \mathrm{t} \mathrm{n} \mathrm{y}$, menghitung pengukuran kinerja dengan $M^{2}$ Measure. Persamaan yang digunakan adalah sebagai berikut (Bodie et al., 2011)

$M^{2}$ Measure $=\left(R_{p}^{*}-R_{\mathrm{m}}\right) \ldots .$.

Di mana:

$\mathrm{R}_{\mathrm{p}^{*}} \quad=$ return reksa dana yang didapatkan dari persamaan (16)

$\mathrm{R}_{\mathrm{m}} \quad=$ return pasar

Jika hasil pengukuran kinerja dengan dengan $M^{2}$ Measure dari produk reksa dana bernilai positif, berarti produk reksa dana tersebut mampu melampaui kinerja pasar apabila total risikonya disamakan dengan risiko pasar (Sutawisena, 2011).

Pengukuran kinerja reksa dana dengan $T^{2}$ Measure adalah pengukuran yang menghitung selisih antara nilai Treynor reksa dana dengan excess return pasar. Persamaan dari pengukuran kinerja reksa dana dengan $T^{2}$ Measure adalah sebagai berikut (Bodie et al., 2011).

$T^{2}$ Measure $=$ Treynor's Measure $-\left(r_{m}-r_{f}\right)$

Di mana:

Treynor's Measure = hasil pengukuran dengan metode Treynor didapatkan dari persamaan (11)

$\mathrm{R}_{\mathrm{m}} \quad=$ return pasar

$\mathrm{R}_{\mathrm{f}}^{\mathrm{m}}=$ return instrumen bebas risiko

Jika hasil pengukuran $T^{2}$ Measure dari produk reksa dana bernilai positif, berarti reksa dana tersebut mampu melampaui kinerja pasar.

Rumusan hipotesis yang diajukan yaitu :

$\mathrm{H}_{1}$ Tidak ada perbedaan secara signifikan rata-rata return dan Risiko reksa dana saham konvensional dan syariah

$\mathrm{H}_{2}$ Tidak ada perbedaan secara signifikan kinerja reksa dana konvensional dan syariah berdasarkan pengukuran Sharpe, Treynor, Jensen, appraisal ratio, $M^{2}$ measure, dan $T^{2}$ measure

HASIL DAN PEMBAHASAN

Return reksadana saham konvesional dalam penelitian ini meliputi 25 Reksadana saham konvensional sedangkan 
Nurul Huda, Dkk

Tabel 1 Return Reksa Dana Saham Konvensional dan Syariah Periode 2012-2015

\begin{tabular}{|c|c|c|c|c|c|c|c|c|}
\hline \multirow{2}{*}{$\begin{array}{l}\text { Reksa } \\
\text { Dana } \\
\text { Saham }\end{array}$} & \multicolumn{2}{|c|}{2012} & \multicolumn{2}{|c|}{2013} & \multicolumn{2}{|c|}{2014} & \multicolumn{2}{|c|}{2015} \\
\hline & Return & Rank & Return & Rank & Return & Rank & Return & Rank \\
\hline RDSK01 & 0,00415 & 29 & 0,01976 & 3 & 0,02223 & 9 & $-0,013212$ & 23 \\
\hline RDSK02 & 0,00945 & 16 & $-0,00714$ & 28 & 0,02217 & 11 & $-0,011112$ & 16 \\
\hline RDSK03 & 0,00999 & 13 & $-0,01208$ & 32 & 0,02086 & 15 & $-0,009592$ & 14 \\
\hline RDSK04 & 0,00903 & 18 & $-0,00323$ & 20 & 0,02059 & 18 & $-0,008052$ & 12 \\
\hline RDSK05 & 0,01349 & 8 & $-0,00095$ & 12 & 0,02473 & 4 & $-0,019031$ & 28 \\
\hline RDSK06 & 0,00963 & 14 & $-0,00343$ & 21 & 0,02060 & 17 & $-0,007673$ & 11 \\
\hline RDSK07 & 0,00468 & 27 & $-0,00067$ & 11 & 0,01726 & 25 & $-0,007262$ & 9 \\
\hline RDSK08 & 0,00659 & 22 & $-0,00223$ & 16 & 0,02244 & 8 & $-0,007498$ & 10 \\
\hline RDSK09 & 0,01350 & 7 & $-0,00419$ & 24 & 0,02321 & 7 & $-0,010997$ & 15 \\
\hline RDSK10 & 0,00955 & 15 & $-0,00369$ & 22 & 0,01760 & 24 & $-0,047216$ & 32 \\
\hline RDSK11 & 0,00593 & 24 & $-0,00099$ & 13 & 0,01439 & 30 & 0,010887 & 1 \\
\hline RDSK12 & 0,01012 & 12 & $-0,00283$ & 18 & 0,01842 & 22 & $-0,011832$ & 18 \\
\hline RDSK13 & 0,00915 & 17 & $-0,00300$ & 19 & 0,01977 & 20 & $-0,014492$ & 26 \\
\hline RDSK14 & 0,00443 & 28 & 0,04822 & 1 & 0,00557 & 32 & $-0,004389$ & 4 \\
\hline RDSK15 & 0,02334 & 1 & $-0,00195$ & 15 & 0,01223 & 31 & $-0,006745$ & 7 \\
\hline RDSK16 & 0,00082 & 32 & 0,01272 & 5 & 0,03358 & 1 & $-0,005441$ & 5 \\
\hline RDSK17 & 0,00356 & 31 & 0,02114 & 2 & 0,03036 & 2 & $-0,006456$ & 6 \\
\hline RDSK18 & 0,00585 & 25 & $-0,00692$ & 27 & 0,02526 & 3 & $-0,008593$ & 13 \\
\hline RDSK19 & 0,00745 & 20 & 0,00093 & 9 & 0,02075 & 16 & $-0,006958$ & 8 \\
\hline RDSK20 & 0,00846 & 19 & 0,00298 & 7 & 0,02180 & 13 & $-0,003985$ & 3 \\
\hline RDSK21 & 0,00365 & 30 & $-0,00099$ & 14 & 0,02016 & 19 & $-0,002105$ & 2 \\
\hline RDSK22 & 0,01267 & 11 & 0,00668 & 6 & 0,02099 & 14 & $-0,012838$ & 20 \\
\hline RDSK23 & 0,02096 & 2 & $-0,00642$ & 26 & 0,01524 & 29 & $-0,016139$ & 27 \\
\hline RDSK24 & 0,01303 & 10 & $-0,00761$ & 29 & 0,02374 & 6 & $-0,012879$ & 21 \\
\hline RDSK25 & 0,01485 & 4 & $-0,01048$ & 31 & 0,02406 & 5 & $-0,021726$ & 30 \\
\hline RDSS01 & 0,01323 & 9 & 0,01553 & 4 & 0,01586 & 27 & $-0,01363$ & 24 \\
\hline RDSS02 & 0,01464 & 5 & 0,00050 & 10 & 0,01824 & 23 & $-0,01313$ & 22 \\
\hline RDSS03 & 0,00608 & 23 & $-0,00249$ & 17 & 0,02218 & 10 & $-0,02107$ & 29 \\
\hline RDSS04 & 0,01421 & 6 & 0,00261 & 8 & 0,01936 & 21 & $-0,01160$ & 17 \\
\hline
\end{tabular}




\begin{tabular}{|c|c|c|c|c|c|c|c|c|}
\hline RDSS05 & 0,00670 & 21 & $-0,01016$ & 30 & 0,01626 & 26 & $-0,01274$ & 19 \\
\hline RDSS06 & 0,00576 & 26 & $-0,00387$ & 23 & 0,01552 & 28 & $-0,02670$ & 31 \\
\hline RDSS07 & 0,01530 & 3 & $-0,00425$ & 25 & 0,02216 & 12 & $-0,01441$ & 25 \\
\hline Average & 0,0097 & & 0,00098 & & 0,02024 & & $-0,01183$ & \\
\hline
\end{tabular}

\section{Catatan : RDSK = Reksadana saham Konvensional RDSS = Reksadana saham syariah}

Sumber : Pusat Data Kontan, data diolah reksadana saham syariah sebanyak 7. Return yang diperoleh masing-masing reksadana saham sebagai berikut :

Return reksadana saham syariah masuk dalam 5 besar return terbesar pada tahun 2012 dan 2013. Pada tahun 2012 RDSS07(TRIM Syariah Saham) return sebesar 1,53 \% dan RDSS02 (BNP Paribas Pesona Syariah) return sebesar 1,46\% masing-masing masuk ranking 3 dan 5 sedangkan RDSS04 (Cipta Syariah Equity) rangking 6. Tahun 2013 hanya ada satu reksadana saham syariah yang masuk dalam rangking 5 besar yaitu RDSS01 (Batavia Dana Saham Syariah) return sebesar $1,55 \%$, sedangkan tahun 2014 dan 2015 tak ada satupun reksadana saham syariah yang masuk dalam kategori rangking lima besar.

Keterbatasan investasi pada saham syariah menjadi salah satu penyebab rendahnya return saham syariah. Tahun 2015 menjadi tahun terberat reksadana saham karena average return bernilai negative atau mengalami kerugian tak terkecuali reksadana saham syariah. Rata-rata return Reksadana saham syariah berada di atas ratarata Reksadana saham konvensional

Hasil output uji PairedSamples $T$ Test return reksa dana saham bernilai 0,104 atau dengan kata lain Sig > 0,05, maka $\mathrm{H}_{0}$ "diterima". Kesimpulannya adalah ratarata return reksa dana saham konvensional dan syariah tidak berbeda secara signifikan pada level a 5\%. Hasil ini berbeda dengan penelitian yang dilakukan Desiana dan

Tabel 2. Risiko Reksa Dana Saham Konvensional dan Syariah Periode 2012-2015

\begin{tabular}{|c|c|c|c|c|c|c|c|c|}
\hline \multirow{2}{*}{$\begin{array}{c}\text { Reksa } \\
\text { Dana } \\
\text { Saham }\end{array}$} & \multicolumn{2}{|c|}{$\mathbf{2 0 1 2}$} & \multicolumn{2}{c|}{$\mathbf{2 0 1 3}$} & \multicolumn{2}{c|}{$\mathbf{2 0 1 4}$} & \multicolumn{2}{c|}{$\mathbf{2 0 1 5}$} \\
\cline { 2 - 9 } & Nilai & Rank & Nilai & Rank & Nilai & Rank & Nilai & Rank \\
\hline RDSK01 & 0,03816 & 27 & 0,02488 & 32 & 0,02698 & 10 & 0,03914 & 31 \\
\hline RDSK02 & 0,03899 & 23 & 0,06473 & 5 & 0,02307 & 21 & 0,05422 & 11 \\
\hline
\end{tabular}




\begin{tabular}{|c|c|c|c|c|c|c|c|c|}
\hline RDSK03 & 0,04349 & 11 & 0,06898 & 4 & 0,02181 & 25 & 0,06248 & 6 \\
\hline RDSK04 & 0,04069 & 14 & 0,05316 & 19 & 0,02087 & 29 & 0,05196 & 13 \\
\hline RDSK05 & 0,04068 & 15 & 0,05300 & 20 & 0,02245 & 22 & 0,05662 & 7 \\
\hline RDSK06 & 0,03833 & 25 & 0,05450 & 17 & 0,02223 & 23 & 0,05051 & 18 \\
\hline RDSK07 & 0,04010 & 17 & 0,05203 & 24 & 0,02044 & 30 & 0,05214 & 12 \\
\hline RDSK08 & 0,03643 & 29 & 0,05688 & 14 & 0,02346 & 19 & 0,05470 & 10 \\
\hline RDSK09 & 0,04056 & 16 & 0,06375 & 6 & 0,03085 & 5 & 0,05566 & 8 \\
\hline RDSK10 & 0,04320 & 12 & 0,06083 & 8 & 0,02114 & 28 & 0,10478 & 1 \\
\hline RDSK11 & 0,02845 & 32 & 0,04159 & 29 & 0,01384 & 32 & 0,09290 & 2 \\
\hline RDSK12 & 0,03623 & 30 & 0,04767 & 27 & 0,02155 & 26 & 0,05161 & 14 \\
\hline RDSK13 & 0,04280 & 13 & 0,05914 & 10 & 0,02317 & 20 & 0,05495 & 9 \\
\hline RDSK14 & 0,03559 & 31 & 0,06940 & 3 & 0,02451 & 15 & 0,07128 & 3 \\
\hline RDSK15 & 0,04451 & 10 & 0,04550 & 28 & 0,01770 & 31 & 0,04742 & 23 \\
\hline RDSK16 & 0,04628 & 7 & 0,07194 & 2 & 0,03568 & 2 & 0,06562 & 5 \\
\hline RDSK17 & 0,04824 & 4 & 0,08785 & 1 & 0,03573 & 1 & 0,06739 & 4 \\
\hline RDSK18 & 0,04453 & 9 & 0,05745 & 12 & 0,02722 & 9 & 0,05140 & 16 \\
\hline RDSK19 & 0,03948 & 19 & 0,05579 & 16 & 0,02435 & 17 & 0,04562 & 28 \\
\hline RDSK20 & 0,03864 & 24 & 0,05209 & 22 & 0,02437 & 16 & 0,04884 & 19 \\
\hline RDSK21 & 0,03967 & 18 & 0,05115 & 25 & 0,02151 & 27 & 0,05129 & 17 \\
\hline RDSK22 & 0,04508 & 8 & 0,05708 & 13 & 0,02932 & 8 & 0,04797 & 21 \\
\hline RDSK23 & 0,03798 & 28 & 0,06157 & 7 & 0,03081 & 6 & 0,05158 & 15 \\
\hline RDSK24 & 0,04730 & 5 & 0,05205 & 23 & 0,02530 & 13 & 0,04679 & 25 \\
\hline RDSK25 & 0,04719 & 6 & 0,06071 & 9 & 0,03337 & 3 & 0,04682 & 24 \\
\hline RDSS01 & 0,05069 & 3 & 0,03109 & 31 & 0,03137 & 4 & 0,04155 & 30 \\
\hline RDSS02 & 0,03933 & 21 & 0,05271 & 21 & 0,02351 & 18 & 0,04787 & 22 \\
\hline RDSS03 & 0,03907 & 22 & 0,05093 & 26 & 0,02932 & 7 & 0,04802 & 20 \\
\hline RDSS04 & 0,03818 & 26 & 0,03857 & 30 & 0,02218 & 24 & 0,04606 & 27 \\
\hline RDSS05 & 0,03941 & 20 & 0,05891 & 11 & 0,02454 & 14 & 0,04636 & 26 \\
\hline RDSS06 & 0,05141 & 2 & 0,05335 & 18 & 0,02642 & 11 & 0,03652 & 32 \\
\hline RDSS07 & 0,05276 & 1 & 0,05616 & 15 & 0,02605 & 12 & 0,04287 & 29 \\
\hline Average & 0,04167 & & 0,05517 & & 0,02516 & & & \\
\hline
\end{tabular}

Sumber : Pusat Data Kontan, data diolah 
Isnurhadi (2012).

Perbandingan risiko reksadana saham syariah dan konvensional tersaji pada tabel berikut ini :

Rata-rata

risiko tertinggi selama periode 20122015 sebesar 5,517\% (tahun 2013) dan terendah 2,516\% (tahun 2014). Tahun 2012 dua reksadana saham syariah memiliki memiliki risiko tertinggi pertama dan kedua masing-masing RDSS07 (TRIM

\section{Tabel 3. Kinerja Reksa Dana Saham Konvensional dan Syariah Berdasarkan Indeks Sharpe Periode 2012-2015}

\begin{tabular}{|c|c|c|c|c|c|c|c|c|}
\hline & \multicolumn{2}{|c|}{2012} & \multicolumn{2}{|c|}{2013} & \multicolumn{2}{|c|}{2014} & \multicolumn{2}{|c|}{2015} \\
\hline $\begin{array}{c}\text { Rank } \\
\text { Tertinggi }\end{array}$ & $\begin{array}{l}\text { Reksa } \\
\text { Dana }\end{array}$ & Nilai & $\begin{array}{l}\text { Reksa } \\
\text { Dana }\end{array}$ & Nilai & $\begin{array}{l}\text { Reksa } \\
\text { Dana }\end{array}$ & Nilai & $\begin{array}{l}\text { Reksa } \\
\text { Dana }\end{array}$ & Nilai \\
\hline 1 & RDSK23 & 0,65457 & RDSK14 & 0,20457 & RDSK11 & 1,31295 & RDSK19 & 0,28601 \\
\hline 2 & $\begin{array}{l}\text { RDSK15 } \\
\end{array}$ & 0,61197 & RDSK17 & $-0,14663$ & RDSK05 & 1,27000 & RDSK21 & 0,27911 \\
\hline 3 & RDSS04 & 0,47432 & RDSK16 & $-0,29605$ & RDSK04 & 1,16762 & RDSK17 & 0,26913 \\
\hline 4 & RDSS02 & 0,47150 & RDSK22 & $-0,47896$ & RDSK03 & 1,12971 & RDSK20 & 0,25286 \\
\hline 5 & RDSK09 & 0,42913 & RDSK01 & $-0,57323$ & RDSK02 & 1,12491 & RDSK16 & 0,18009 \\
\hline $\begin{array}{c}\text { Rank } \\
\text { Terendah }\end{array}$ & $\begin{array}{l}\text { Reksa } \\
\text { Dana }\end{array}$ & Nilai & $\begin{array}{l}\text { Reksa } \\
\text { Dana }\end{array}$ & Nilai & $\begin{array}{l}\text { Reksa } \\
\text { Dana }\end{array}$ & Nilai & $\begin{array}{l}\text { Reksa } \\
\text { Dana }\end{array}$ & Nilai \\
\hline 28 & RDSK01 & 0,21098 & RDSK12 & $-0,77299$ & RDSS05 & 0,81686 & RDSS05 & $-0,00241$ \\
\hline 29 & RDSK21 & 0,19035 & RDSK15 & $-0,79056$ & RDSS06 & 0,73026 & RDSK25 & $-0,00409$ \\
\hline 30 & RDSS06 & 0,18792 & RDSK24 & $-0,79982$ & RDSS01 & 0,62582 & RDSS01 & $-0,00416$ \\
\hline 31 & RDSK17 & 0,15468 & RDSS04 & $-0,81458$ & RDSK23 & 0,61714 & RDSS03 & $-0,01613$ \\
\hline 32 & RDSK16 & 0,10205 & RDSK11 & $-0,84166$ & RDSK14 & 0,38140 & RDSS06 & $-0,14713$ \\
\hline
\end{tabular}

Sumber : Pusat Data Kontan, data diolah

Syariah Saham ) risiko sebesar $5,28 \%$ dan RDSS06 (PNM Ekuitas Syariah) risiko sebesar 5,14\%. TRIM Syariah Saham pada tahun yang sama juga memberikan return terbesar ketiga, hal ini tentu sejalan dengan konsep high return high risk.

Terkait apakah ada perbedaan yang berarti antara risiko saham syariah dan konvensional maka hasil uji hipotesis menyatakan tidak ada perbedaan yang berarti.

$$
\text { Gambaran }
$$

umum mengenai tingkat dan pemeringkatan kinerja reksa dana saham konvensional dan syariah dengan indeks Sharpe periode 2012-2015 untuk lima 
syariah yang masuk dalam lima reksadana yang memiliki kinerja terbaik masing masing Cipta Syariah Equity (RDSS04) rangking 3 dengan nilai sharpe 0,47432 dan BNP Paribas

Pesona Syariah (RDSS02) rangking 4 dengan nilai sharpe hipotesis ternyata Ho di terima berarti tidak dapat perbedaan berarti antara kinerja sharpe reksadana saham syariah dan konvensional .

$$
\text { Gambaran }
$$

umum mengenai tingkat dan pemeringkatan kinerja reksa

\section{Tabel 4. Kinerja Reksa Dana Saham Konvensional dan Syariah Berdasarkan Indeks Treynor Periode 2012-2015}

\begin{tabular}{|c|c|c|c|c|c|c|c|c|}
\hline & \multicolumn{2}{|c|}{2012} & \multicolumn{2}{|c|}{2013} & \multicolumn{2}{|c|}{2014} & \multicolumn{2}{|c|}{2015} \\
\hline $\begin{array}{c}\text { Rank } \\
\text { Tertinggi }\end{array}$ & $\begin{array}{l}\text { Reksa } \\
\text { Dana }\end{array}$ & Nilai & $\begin{array}{l}\text { Reksa } \\
\text { Dana }\end{array}$ & Nilai & $\begin{array}{l}\text { Reksa } \\
\text { Dana }\end{array}$ & Nilai & $\begin{array}{l}\text { Reksa } \\
\text { Dana }\end{array}$ & Nilai \\
\hline 1 & RDSK23 & 0,02688 & RDSS01 & 0,12425 & RDSK 14 & 0,05630 & RDSS01 & 0,03450 \\
\hline 2 & RDSK15 & 0,02530 & RDSK14 & 0,01444 & RDSK24 & 0,02661 & RDSK14 & 0,01763 \\
\hline$\frac{3}{4}$ & $\frac{\mathrm{RDSS} 04}{\mathrm{RDSSO2}}$ & $\begin{array}{l}0,02264 \\
0,02151\end{array}$ & RDSK 1 & $\begin{array}{l}-0,00799 \\
-0,01559\end{array}$ & $\frac{\mathrm{RDSK} 11}{\mathrm{RDSS} 04}$ & $\begin{array}{l}0,02602 \\
0,02462\end{array}$ & $\frac{\text { RDSK } 17}{\text { RDSK } 16}$ & $\begin{array}{l}0,00321 \\
0,00176\end{array}$ \\
\hline $\begin{array}{c}\text { Rank } \\
\text { Terendah }\end{array}$ & $\begin{array}{l}\text { Reksa } \\
\text { Dana }\end{array}$ & Nilai & $\begin{array}{l}\text { Reksa } \\
\text { Dana }\end{array}$ & Nilai & $\begin{array}{l}\text { Reksa } \\
\text { Dana }\end{array}$ & Nilai & $\begin{array}{c}\text { Reksa } \\
\text { Dana }\end{array}$ & Nilai \\
\hline 28 & RDSK18 & 0,00846 & RDSK24 & $-0,04063$ & RDSK12 & 0,01864 & RDSK 25 & $-0,00559$ \\
\hline$\frac{29}{30}$ & $\begin{array}{l}\text { RDSK01 } \\
\text { RDSK } 21\end{array}$ & $\begin{array}{l}0,00818 \\
0,00727\end{array}$ & $\begin{array}{l}\text { RDSK 15 } \\
\text { RDSK 11 }\end{array}$ & $\begin{array}{l}-0,04101 \\
-0,04372\end{array}$ & $\begin{array}{l}\text { RDSK099 } \\
\text { RDSSO1 }\end{array}$ & 0,01767 & RDSSO3 & $-0,00617$ \\
\hline 31 & & 0,00663 & RDSSSO4 & $\begin{array}{l}-0,04312 \\
-0,04590\end{array}$ & & 0,01585 & RDSK10 & $\begin{array}{l}-0,01201 \\
-0,02047\end{array}$ \\
\hline
\end{tabular}

Sumber : Pusat Data Kontan, data diolah

0,47150. Sebailknya reksadana saham syariah yang masuk rangking terendah dalam kinerja sharpe yaitu PNM Ekuitas Syariah (RDSS06) rangking 30 dengan nilai sharpe 0,18792. Sedangkan untuk tahun 2013-2015 tidak ada satupun reksadana saham syariah yang masuk dalam lima besar kinerja terbaik reksadana saham. Bahkan tahun 2014 terdapat 3 reksadana saham syariah yang masuk rangking 28-30, untuk tahun 2015 bahkan 4 reksadana saham syariah yang masuk dalam kinerja terburuk. Berdasarkan uji dana saham konvensional dan syariah dengan indeks Treynor periode 2012-2015 secara jelas dapat dilihat pada Tabel berikut ini.

Perhitungan dengan indeks Treynor selama periode 2012 sd 2015 hampir setiap tahun reksadana saham syariah ada menempati rangking 5 besar terbaik dalam hal kinerjanya.

Periode tahun 2012 adalah reksa dana Syailendra Equity Opportunity Fund, MNC Dana Ekuitas, Cipta Syariah Equity (RDSS04), BNP Paribas Pesona Syariah (RDSS02), dan TRIM Syariah Saham (RDSS07) seperti yang ditunjukkan pada 
Tabel 4 Kelima reksa dana tersebut memiliki kinerja yang tinggi berdasarkan penambahan investasi yang diperoleh (excess return) untuk setiap unit total systematic risk yang timbul jika dibandingkan dengan produk reksa dana yang lain dalam sampel penelitian. Pada tahun 2015 Reksadana saham syariah Batavia Dana Saham Syariah (RDSS02) menduduki peringkat pertama dengan kinerja terbaik dengan indeks Treynor.

Terkait adakah perbedaan berarti kinerja reksadana saham syariah dan konvensional dengan pendekatan indeks Treynor, berdasarkan perhitungan nilai sig $>0,05$ yang berarti tidak terdapat perbedaan yang berarti antara kinerja saham syariah dengan konvensional.

Gambaran mengenai tingkat

umum pemeringkatan kinerja reksa dana saham konvensional dan syariah dengan indeks Jensen periode 2012-2015 secara jelas dapat dilihat pada Tabel 5 berikut ini.

Tahun 2012 terdapat 3 reksadana Syariah yang masuk dalam 5 besar yang memiliki kinerja terbaik Cipta Syariah Equity (RDSS04), BNP Paribas Pesona Syariah (RDSS02) , dan TRIM Syariah Saham (RDSS07) seperti pada Tabel 5 ketiga reksa dana tersebut memiliki kinerja superior yang paling tinggi dibandingkan dengan produk reksa dana lain dalam sampel penelitian. Manajer investasi dari kelima reksa dana tertinggi tersebut memiliki kemampuan dalam memprediksi pergerakan pasar dan cepat merespons terhadap perubahan yang terjadi di pasar sehingga mampu memberikan kinerja diatas kinerja pasar sesuai

Tabel 5. Kinerja Reksa Dana Saham Konvensional dan Syariah Berdasarkan Indeks Jensen Periode 2012-2015

\begin{tabular}{|c|c|c|c|c|c|c|c|c|}
\hline & \multicolumn{2}{|c|}{2012} & \multicolumn{2}{|c|}{2013} & \multicolumn{2}{|c|}{2014} & \multicolumn{2}{|c|}{2015} \\
\hline $\begin{array}{c}\text { Rank } \\
\text { Tertinggi }\end{array}$ & $\begin{array}{c}\text { Reksa } \\
\text { Dana } \\
\end{array}$ & Nilai & $\begin{array}{c}\text { Reksa } \\
\text { Dana }\end{array}$ & Nilai & $\begin{array}{c}\text { Reksa } \\
\text { Dana }\end{array}$ & Nilai & $\begin{array}{c}\text { Reksa } \\
\text { Dana }\end{array}$ & Nilai \\
\hline 1 & RDSK15 & 0,01212 & RDSK14 & 0,04845 & RDSS04 & 0,00656 & RDSK14 & 0,01345 \\
\hline 2 & RDSK23 & 0,01187 & RDSK 17 & 0,04329 & RDSS07 & 0,00634 & RDSK 17 & 0,01148 \\
\hline 3 & RDSS04 & 0,00818 & RDSK16 & 0,02631 & RDSK24 & 0,00627 & RDSK16 & 0,00807 \\
\hline 4 & RDSS02 & 0,00784 & RDSK22 & 0,01185 & RDSK14 & 0,00594 & RDSK11 & 0,00659 \\
\hline 5 & RDSS07 & 0,00715 & RDSS02 & 0,00753 & RDSK16 & 0,00580 & RDSS02 & 0,00408 \\
\hline $\begin{array}{c}\text { Rank } \\
\text { Terendah }\end{array}$ & $\begin{array}{c}\text { Reksa } \\
\text { Dana }\end{array}$ & Nilai & $\begin{array}{c}\text { Reksa } \\
\text { Dana }\end{array}$ & Nilai & $\begin{array}{c}\text { Reksa } \\
\text { Dana }\end{array}$ & Nilai & $\begin{array}{c}\text { Reksa } \\
\text { Dana }\end{array}$ & Nilai \\
\hline 28 & RDSK01 & $-0,00577$ & RDSK24 & $-0,00593$ & RDSK12 & $-0,00222$ & RDSK25 & $-0,00180$ \\
\hline 29 & RDSK18 & $-0,00643$ & RDSK11 & $-0,00711$ & RDSK13 & $-0,00241$ & RDSS06 & $-0,00452$ \\
\hline 30 & RDSK21 & $-0,00704$ & RDSS04 & $-0,00719$ & RDSK09 & $-0,00439$ & RDSK01 & $-0,00523$ \\
\hline 31 & RDSK17 & $-0,00834$ & RDSK01 & $-0,00963$ & RDSK22 & $-0,00733$ & RDSS01 & $-0,00614$ \\
\hline 32 & RDSK16 & $-0,01139$ & RDSS01 & $-0,02376$ & RDSK 23 & $-0,01219$ & RDSK10 & $-0,01069$ \\
\hline
\end{tabular}

Sumber : Pusat Data Kontan, data diolah 
risiko yang dimilikinya.

Sedangkan untuk tahun 2013-2015 untuk reksadana syariah, tahun 2014 dua reksadana syariah menjadi dua reksadana syariah dengan kinerja terbaik yaitu Cipta Syariah Equity (RDSS04) dan TRIM Syariah Saham (RDSS07). Sebaliknya untuk reksadana dengan kinerja terburuk tahun 2012 dan 2014 tidak ada satupun berasal dari reksadana saham syariah.

Berdasarkan uji paired sample test ternyata tidak terdapat perbedaan yang berarti kinerja reksadana saham syariah dengan konvensional.

Kinerja Appraisal Ratio
Kinerja

saham

syariah

reksadana

pendekatan Appraisal ratio hanya pada tahun 2013 saja yang tidak masuk dalam 5 reksadana saham dengan kinerja terbaik. Bahkan tahun 2014 dan 2015 Reksadana saham syariah menjadi reksadana saham dengan kinerja terbaik pertama masing masing Cipta Syariah Equity (RDSS04) dan BNP Paribas Pesona Syariah (RDSS02).

Sedangkan reksadana saham syariah yang memiliki kinerja terburuk selama periode 2012-2015 hanya ada satu yaitu Batavia Dana Saham Syariah (RDSS01) pada tahun 2013 dan tahun 2015 pada

Tabel 6 Kinerja Reksa Dana Saham Konvensional dan Syariah Berdasarkan Appraisal Ratio Periode 2012-2015

\begin{tabular}{|c|c|c|c|c|c|c|c|c|}
\hline & \multicolumn{2}{|c|}{2012} & \multicolumn{2}{|c|}{2013} & \multicolumn{2}{|c|}{2014} & \multicolumn{2}{|c|}{2015} \\
\hline $\begin{array}{c}\text { Rank } \\
\text { Tertinggi }\end{array}$ & $\begin{array}{c}\text { Reksa } \\
\text { Dana }\end{array}$ & Nilai & $\begin{array}{c}\text { Reksa } \\
\text { Dana }\end{array}$ & Nilai & $\begin{array}{c}\text { Reksa } \\
\text { Dana }\end{array}$ & Nilai & $\begin{array}{c}\text { Reksa } \\
\text { Dana }\end{array}$ & Nilai \\
\hline 1 & RDSK23 & 0,75946 & RDSK17 & 1,21334 & RDSS04 & 0,63958 & RDSS02 & 0,36488 \\
\hline 2 & RDSSO2 & & RDSK 16 & & RDSK II & & RDSK 17 & \\
\hline 3 & RDSK15 & 0,64056 & RDSK22 & 1 & RDSS07 & 0,53950 & RDSK16 & 0,29141 \\
\hline 4 & RDSS04 & 0,54925 & RDSK14 & 0,98490 & RDSK05 & 0,49226 & RDSK14 & 0,26617 \\
\hline 5 & RDSK05 & 0,28641 & RDSK08 & 0,40928 & RDSS02 & 0,48376 & RDSK20 & 0,24744 \\
\hline $\begin{array}{c}\text { Rank } \\
\text { Terendah }\end{array}$ & $\begin{array}{c}\text { Reksa } \\
\text { Dana }\end{array}$ & Nilai & $\begin{array}{c}\text { Reksa } \\
\text { Dana }\end{array}$ & Nilai & $\begin{array}{c}\text { Reksa } \\
\text { Dana }\end{array}$ & Nilai & $\begin{array}{c}\text { Reksa } \\
\text { Dana }\end{array}$ & Nilai \\
\hline 28 & RDSK17 & $-0,35452$ & RDSK15 & $-0,42446$ & RDSK07 & $-0,32848$ & RDSK25 & $-0,14806$ \\
\hline 29 & RDSK01 & $-0,57890$ & RDSK12 & $-0,42631$ & RDSK13 & $-0,35697$ & RDSK10 & $-0,19250$ \\
\hline 30 & RDSK18 & $-0,57923$ & RDSK24 & $-0,57654$ & RDSK12 & $-0,40777$ & RDSS01 & $-0,24865$ \\
\hline 31 & RDSK16 & $-0,65851$ & RDSK11 & $-0,60096$ & RDSK22 & $-0,70461$ & RDSK06 & $-0,29452$ \\
\hline 32 & 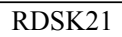 & $-0,88962$ & RDSS01 & $-0,77999$ & RDSK23 & $-0,78789$ & RDSK01 & $-0,36411$ \\
\hline
\end{tabular}

Sumber : Pusat Data Kontan, data diolah

tertinggi dan terendah dari rangking 32 dan 30. Reksa sampel reksa dana saham dana tersebut memiliki kinerja dalam penelitian tergambar inferior jika dibandingkan pada tabel di bawah ini : dengan produk reksa dana 
yang lain dalam sampel kinerja $M^{2}$ Measure tertinggi penelitian. Manajer investasi dan lima terendah dari sampel dari kelima reksa dana tersebut reksa dana saham dalam memiliki kemampuan inferior penelitian.

manajer investasi untuk setiap nonsystematic risk yang dimiliki.

Selain itu terdapat perbedaan yang signifikan kinerja reksadana saham syariah dan konvensional berdasarjkan uji paired sample test.

Pada bagian ini akan dilakukan pembahasan mengenai Perbedaan kinerja reksa dana saham dengan pendekatan $M^{2}$ Measure selama periode 2012-2015 kemudian hasil dari perhitungan kinerja akan dilakukan pemeringkatan lima dengan

2012-2015 kinerja periode syariah dengan pendekatan $M^{2}$ Measure cukup mendominasi sebagai saham dengan kinerja terbaik, pada tahun 2012 terdapat 3 reksadana sayriah masuk peringat lima besar yaitu rangking 3,4 dan 5 terbaik masing-masing Cipta Syariah Equity (RDSS04) dan BNP Paribas Pesona Syariah (RDSS02) serta TRIM Syariah Saham (RDSS07). Bahkan pada tahun 2014 dua reksada syariah dari tiga yang masuk dalam rangking 5 besar menduduki posisi terbaik

\section{Tabel 7. Kinerja Reksa Dana Saham Konvensional dan Syariah} Berdasarkan $M^{2}$ Measure Periode 2012-2015

\begin{tabular}{|c|c|c|c|c|c|c|c|c|}
\hline & \multicolumn{2}{|c|}{2012} & \multicolumn{2}{|c|}{2013} & \multicolumn{2}{|c|}{2014} & \multicolumn{2}{|c|}{2015} \\
\hline $\begin{array}{c}\text { Rank } \\
\text { Tertinggi }\end{array}$ & $\begin{array}{l}\text { Reksa } \\
\text { Dana }\end{array}$ & Nilai & $\begin{array}{c}\text { Reksa } \\
\text { Dana }\end{array}$ & Nilai & $\begin{array}{c}\text { Reksa } \\
\text { Dana }\end{array}$ & Nilai & $\begin{array}{c}\text { Reksa } \\
\text { Dana }\end{array}$ & Nilai \\
\hline 1 & RDSK 23 & 0,01045 & RDSK14 & 0,04503 & RDSS04 & 0,00419 & RDSK14 & 0,00902 \\
\hline 2 & RDSK15 & 0,00886 & RDSK17 & 0,02754 & RDSS07 & 0,00320 & RDSK17 & 0,00601 \\
\hline 3 & RDSS04 & 0,00843 & RDSK16 & 0,02010 & RDSK11 & 0,00249 & RDSS02 & 0,00450 \\
\hline 4 & RDSS02 & 0,00831 & RDSK22 & 0,01099 & RDSS02 & 0,00196 & RDSK16 & 0,00419 \\
\hline 5 & RDSS07 & 0,00358 & RDSS01 & 0,01062 & RDSK05 & 0,00174 & RDSS04 & 0,00349 \\
\hline $\begin{array}{c}\text { Rank } \\
\text { Terendah }\end{array}$ & $\begin{array}{l}\text { Reksa } \\
\text { Dana }\end{array}$ & Nilai & $\begin{array}{l}\text { Reksa } \\
\text { Dana }\end{array}$ & Nilai & $\begin{array}{l}\text { Reksa } \\
\text { Dana }\end{array}$ & Nilai & $\begin{array}{c}\text { Reksa } \\
\text { Dana }\end{array}$ & Nilai \\
\hline 28 & RDSK07 & $-0,00604$ & RDSK25 & $-0,00166$ & RDSK09 & $-0,00520$ & RDSK01 & $-0,00174$ \\
\hline 29 & RDSK01 & $-0,00615$ & RDSK12 & $-0,00365$ & RDSK22 & $-0,00573$ & RDSK24 & $-0,00183$ \\
\hline 30 & RDSK21 & $-0,00692$ & RDSK15 & $-0,00453$ & RDSK25 & $-0,00591$ & RDSK10 & $-0,00202$ \\
\hline 31 & RDSK17 & $-0,00825$ & RDSK24 & $-0,00499$ & RDSK23 & $-0,00972$ & RDSK25 & $-0,00387$ \\
\hline 32 & RDSK16 & $-0,01022$ & RDSK11 & $-0,00707$ & RDSK14 & $-0,01386$ & RDSS06 & $-0,00639$ \\
\hline
\end{tabular}

Sumber : Pusat Data Kontan, data diolah 
pertama dan kedua. Hanya saja pada tahun 2015 terdapat satu reksadana saham syariah yang memiliki kinerja paling buruk dari seluruh reksadana yang ada yaitu PNM Ekuitas Syariah (RDSS06) dan bernilai negatif berarti produk akandilakukan pemeringkatan lima dengan kinerja $T^{2}$ Measure tertinggi dan lima terendah dari sampel reksa dana saham dalam penelitian. Gambaran umum mengenai tingkat dan pemeringkatan kinerja reksa dana saham konvensional dan

Tabel 8. Kinerja Reksa Dana Saham Konvensional dan Syariah Berdasarkan $T^{2}$ Measure Periode 2012-2015

\begin{tabular}{|c|c|c|c|c|c|c|c|c|}
\hline & \multicolumn{2}{|c|}{2012} & \multicolumn{2}{|c|}{2013} & \multicolumn{2}{|c|}{2014} & \multicolumn{2}{|c|}{2015} \\
\hline $\begin{array}{c}\text { Rank } \\
\text { Tertinggi }\end{array}$ & $\begin{array}{l}\text { Reksa } \\
\text { Dana }\end{array}$ & Nilai & $\begin{array}{c}\text { Reksa } \\
\text { Dana }\end{array}$ & Nilai & $\begin{array}{c}\text { Reksa } \\
\text { Dana }\end{array}$ & Nilai & $\begin{array}{c}\text { Reksa } \\
\text { Dana }\end{array}$ & Nilai \\
\hline & RDSK23 & 0,01283 & $\begin{array}{c}\text { Dana } \\
\text { RDSS01 }\end{array}$ & 0,15964 & $\begin{array}{c}\text { Nana } \\
\text { RDSK14 }\end{array}$ & 0,03575 & $\begin{array}{c}\text { Dana } \\
\text { RDSS01 }\end{array}$ & 0,03960 \\
\hline & $\frac{R D S K 15}{R D S S 04}$ & $\frac{0.01126}{0.01022}$ & $\begin{array}{l}\mathrm{RDSK} 14 \\
\mathrm{RDSK} 17\end{array}$ & $\frac{0.04929}{0.02685}$ & $\frac{R D S S 04}{R D S K 24}$ & $\frac{0.00698}{0.00607}$ & $\begin{array}{l}\text { RDSK } 14 \\
\text { RDSK } 17\end{array}$ & $\begin{array}{l}0,02130 \\
0.00688\end{array}$ \\
\hline & $\frac{1 \mathrm{RDSO02}}{\mathrm{RDSS07}}$ & $\frac{0.00910}{0.00737}$ & 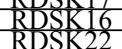 & $\frac{0.01926}{0.01054}$ & 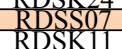 & $\frac{0.00571}{0.00548}$ & $\frac{\mathrm{RDSK} 16}{\mathrm{RDSK} 11}$ & $\frac{0.00543}{0.00411}$ \\
\hline $\begin{array}{c}\text { Rank } \\
\text { Terendah }\end{array}$ & $\begin{array}{l}\text { Rek: } \\
\text { Dan }\end{array}$ & Nilai & $\begin{array}{l}\text { Reksa } \\
\text { Dana }\end{array}$ & Nilai & $\begin{array}{l}\text { Reksa } \\
\text { Dana }\end{array}$ & Nilai & $\begin{array}{l}\text { Reksa } \\
\text { Dana }\end{array}$ & Nilai \\
\hline 28 & RDSK18 & $-0,00558$ & RDSK24 & $-0,00579$ & RDSK10 & $-0,0$ & RDSK25 & $-0,00191$ \\
\hline $\begin{array}{l}29 \\
30 \\
31\end{array}$ & $\begin{array}{l}\text { RDSK01 } \\
\text { RDSK 21 } \\
\text { RDSK17 }\end{array}$ & $\begin{array}{l}-0,00586 \\
-0,00677 \\
-0,00741\end{array}$ & $\begin{array}{l}\text { RDSK } 15 \\
\text { RDSK } 11 \\
\text { RDSSO4 }\end{array}$ & $\begin{array}{l}-0,00617 \\
-0,00888 \\
-0,01051\end{array}$ & $\begin{array}{l}\text { RDSK } 13 \\
\text { RDSK09 } \\
\text { RDSK } 22\end{array}$ & $\begin{array}{l}-0,00191 \\
-0,00288 \\
-0,00469\end{array}$ & $\begin{array}{l}\text { RDSK06 } \\
\text { RDSS06 } \\
\text { RDSK } 10\end{array}$ & $\begin{array}{l}-0,00343 \\
-0,00690 \\
-0,01680\end{array}$ \\
\hline
\end{tabular}

Sumber: Pusat Data Kontan, data diolah

reksa dana tersebut belum mampu melampaui kinerja pasar dengan total risikonya disamakan dengan risiko pasar dibandingkan dengan produk reksa dana yang lain dalam sampel penelitian.

Selain itu tidak terdapat perbedaan yang signifikan kinerja reksadana saham syariah dan konvensional berdasarjkan uji paired sample test

Pada bagian ini akan dilakukan pembahasan mengenai Perbedaan kinerja reksa dana saham dengan pendekatan $T^{2}$ Measure selama periode 2012-2015 kemudian hasil dari perhitungan kinerja syariah dengan $T^{2}$ Measure periode 2012-2015 secara jelas dapat dilihat pada Tabel 8 berikut ini.

Hasil perhitungan pada kinerja Treynor umumnya memiliki hasil yang sama dengan kinerja $T^{2}$. Masingmasing produk reksa dana diukur kemudian diperingkat. Jika diurutkan, maka produk reksa dana yang meraih posisi lima tertinggi berdasarkan $T^{2}$ Measure adalah Syailendra Equity Opportunity Fund (RDSK23), MNC Dana Ekuitas (RDSK15), Cipta Syariah Equity (RDSS04) dan BNP Paribas Pesona Syariah (RDSS02) serta TRIM Syariah 
Saham (RDSS07). seperti yang ditampilkan pada Tabel 8 . Apabila dibandingkan dengan produk reksa dana yang lain dalam sampel penelitian, kelima reksa dana tersebut memiliki kinerja outperformed dengan selisih antara nilai Treynor dan excess return pasar. Produk-produk reksa dana yang meraih posisi lima tertinggi juga bernilai positif, ini menunjukkan bahwa reksa dana tersebut mampu melampaui kinerja pasar.

Sedangkan reksadana dengan nilai terendah memiliki kinerja underperformed dengan selisih antara nilai Treynor dan excess return pasar jika dibandingkan dengan produk reksa dana yang lain dalam sampel penelitian. Produkproduk reksa dana yang meraih posisi lima terendah juga bernilai negatif, ini menunjukkan bahwa reksa dana tersebut belum mampu melampaui kinerja pasar. Selain itu tidak terdapat perbedaan yang signifikan kinerja reksadana saham syariah dan konvensional berdasarjkan uji paired sample test.

\begin{tabular}{lr}
\multicolumn{1}{c}{ Hasil } & penelitian \\
keseluruhan masih \\
mengindikasikan & bahwa \\
ada hasil beda & kinerja \\
reksadana saham syariah & syan kionvensional dengan \\
dan knakn & pengukuran \\
menggunakan
\end{tabular}

yang berbeda, dengan kata lain penelitian ini memperkuat penelitian Lailiyah, Suhadak, Sulasmiyati (2016), Rahmah (2016) dan Sunarsih dan Adrianto, (2015) serta Desiana dan Isnurhadi (2012

\section{PENUTUP}

Berdasarkan pembahasan yang dilakukan maka kesimpulan yang dapat dikemukakan bahwa tidak terdapat yang signifikan perbedaan return reksadana saham syariah, selain itu tidak terdapat perbedaan Risiko reksadana saham syariah dan konvensional. Selain itu tidak terdapat perbedaan yang berarti kineja reksadana saham konvensional dan syariah dengan pendekatan indeks Sharpe, Treynor, Jensen, $M^{2}$ measure, dan $T^{2}$ measure kecuali appraisal ratio, selama periode Januari 2012 sampai dengan Desember 2015. 


\section{DAFTAR PUSTAKA}

Al-Khazali, O., Lean, H. H., dan Samet, A. 2014. Do Islamic stock indices outperform conventional Stock indices? A stochastic dominance approach. Pacific-Basin Finance Journal, 28, 29-46.

Ashraf, Prince Mohammad Bin Fahd (2013), Performance evaluation of Islamic mutual funds relative to conventional funds: Empirical evidence from Saudi Arabia", International Journal of Islamic and Middle Eastern Finance and Management, Vol. 6 Issue: 2, pp.105121.

Bodie, Kane, Marcus. 2003. Investments, Fifth Edition. The McGraw-Hill Companies, Inc. USA.

--------. (2009. Investments, Eighth Edition. McGraw-Hill: Singapore.

------. 2011) Investments and Portfolio Management, Ninth Edition. McGraw-Hill: Singapore.

Desiana, Lidia dan Isnurhadi. 2012. Perbandingan Kinerja Reksa Dana Saham Konvensional dengan Reksa Dana Saham Syariah di Bursa Efek Indonesia. Jurnal Manajemen $\mathcal{E}$ Bisnis Sriwijaya. Vol. 10, No.19.

Dewi, Miranti Kartika dan Ilham Reza Ferdian. 2012. Evaluating Performance of Islamic Mutual Funds in Indonesia and Malaysia, Journal of Applied Economics and Business Research JAEBR, 2(1): 11-33 (2012).

Elfakhani, Said dan M. Kabir Hassan. 2005. Performance of Islamic Mutual Funds. $12^{\text {th }}$ ERF Conference Paper.

El Gamal, M.A. 2000. A Basic Guide to Contemporary Islamic Banking and Finance. Rice University. 
Evans, Charles W. 2015. Bitcoin in Islamic Banking and Finance. Journal of Islamic Banking and Finance. Vol. 3, No. 1, pp. 1-11 DOI: 10.15640/jibf.v3n1a1URL: http://dx.doi. org/10.15640/jibf.v3n1a1.

Farkoosh, Parviz Dindar, Bahloul Dindar Farkoosh, Javad Naseri. 2012. The effect net assets value in purchasing the shares of investment companies, IOSR Journal Of Humanities And Social Science (JHSS)ISSN: 2279-0837, ISBN: 2279-0845. Volume 5, Issue 2 (Nov. - Dec. 2012), PP 17-20.

Habib, M., dan Islam, K. 2014. Performance of shari'ah compliant index: A Comparative Study of India and Malaysia. International Journal of Interdisciplinary and Multidisiplinary Studies (IJIMS), 1(6), 231-241.

Hartono, A.F, Soekarno, Damayanti. 2014 Islamic and Conventional Equity Fund Rating Performance withalReturn, Sharpe, Modified Snail Trail, and Morningstar Rating Groundwork, Journal of Economics, Business and Management, Vol. 2, No. 1, February 2014.

Huda, Nurul dan Mustafa Edwin Nasution. 2014. Investasi Pada Pasar Modal Syariah. Edisi Revisi, cetakan ke-3. Jakarta: Kencana.

Jawadi, F., Jawadi, N., dan Louhichi, W. 2014. Conventional and Islamic stock price performance: an empirical investigation. International Economics, 137, 73-87.

Lailiyah, Elliv Hidayatul, Suhadak, Sri Sulasmiyati. 2016. Analisis Perbandingan Kinerja Reksadana Syariah Dan Reksadana Konvensional (Studi Pada Reksadana Yang Terdaftar Di Otoritas Jasa Keuangan Periode 2012-2016) Jurnal Administrasi Bisnis (JAB) | Vol. 35 No. 2 Juni 2016.

Pratomo, Eko Priyo dan Ubaidillah Nugraha. 2009. Reksa Dana: Solusi Perencanaan Investasi di Era Modern, edisi revisi ke2. Jakarta: Gramedia Pustaka Utama. 
Priyadarshini dan Chandra Babu .2012. A Comparative Analysis for forecasting the NAV's of Indian Mutual Fund using Multiple Regression Analysis and Artificial Neural Networks, International Journal of Trade, Economics and Finance, Vol. 3, No. 5, October 2012.

Putra, Bintang Pratama Buana, Imron Mawardi. 2016. Perbandingan Kinerja Reksadana Syariah Di Indonesia menggunakan metode Sharpe (Studi Kasus Reksadana Syariah Saham, Reksadana Syariah Pendapatan Tetap Dan Reksadana Syariah Campuran Periode 2012-2014), Jurnal Ekonomi Syariah Teori dan Terapan Vol. 3 No. 9 September 2016: 683-698.

Putra, Jepryansyah dan Syarief Fauzie. 2014. Analisis Perbandingan Kinerja Reksa Dana Konvensional Dengan Reksa Dana Syariah Di Indonesia, Jurnal Ekonomi dan Keuangan Vol. 2 No.5.

Rafay, Abdul, Usman Javed Gilani and Muhammad Adnan Izhar (2017), Investigating The Performance Of Islamic Mutual Funds: Evidence From An Emerging Economy, City University Research Journal Volume 07 Number 02 July 2017 PP 234-241.

Rahmah, Azizatur. 2016, Analisis Perbandingan Kinerja Reksa Dana Syariah Dan Kinerja Reksa Dana Konvensional Dengan Metode Sharpe, Treynor Dan Jensen, Analytica Islamica, Vol. 5, No. 1, 2016: 20-40.

Ratnawati, Vince dan Ningrum Khairani. 2012. Perbandingan Kinerja Reksa DanaSyariah dan Reksa DanaKonvensional. Jurnal Akuntansi, Vol. 1, No. 1, Oktober 2012: 96-113.

Ross, Stephen A., Randolph W. Westerfield, dan Jeffrey Jaffe. 2003. Corporate Finance. McGraw-Hill/Irwin, Sixth Edition, USA.

2010. Corporate Finance. McGraw-Hill/Irwin, Ninth Edition, USA.

Sunarsih, Uun dan Adriyanto. 2014. Analysis of the Performance 
of Islamic Mutual Funds in Indonesia by using Sharpe, Treynor and Jensen the Period 2010-2012, Research Journal of Finance and Accounting ISSN 2222-1697 (Paper) ISSN 2222-2847 (Online) Vol.6, No.3, 2015.

Sutawisena, A.A.N. 2011. Analisis Pola Kinerja Reksa Dana Saham, Reksa Dana Pendapatan Tetap dan Reksa Dana Campuran di Indonesia Selama Periode 2005-2010. Tesis Fakultas Ekonomi, Program Studi Magister Manajemen Universitas Indonesia, Jakarta.

http://www.ojk.go.id/sharia-capital-id (diakses pada tanggal 11 April 2016 jam 09.20 WIB).

http://www.idx.co.id/ (diakses pada tanggal 7 April 2016 jam 10.15 WIB).

h t t p : / / w w w b b o o m b e r g. com / a p p s / data\%3Fpid\%3Dfundscreener (diakses pada tanggal 6 April 2016 jam 13.10 WIB).

http://www.infovesta.com/ (diakses pada tanggal 5 April 2016 jam 14.50 WIB).

http://aria.bapepam.go.id/reksadana/ (diakses pada tanggal 6 April 2016 jam 08.30 WIB).

http://pusatdata.kontan.co.id/ (diakses pada tanggal 15 April 2016 jam 10.45 WIB). 